\title{
The Effect of Service Quality and Customers' Relationship Management on Customers' Loyalty at Bank BSI KC Bengkulu S. \\ Parman 2
}

\section{Pengaruh Service Quality dan Costumer Releationship Management Terhadap Loyalitas Nasabah Pada Bank BSI KC Bengkulu S.Parman 2}

\author{
Mita Handayani 1); Merta Kusuma 2) \\ 1,2) Program Studi Manajemen, Fakultas Ekonomi dan Bisnis, Universitas Muhammadiyah Bengkulu \\ Email: ${ }^{1)}$ mitahandayani303@gmail.com; ${ }^{2)}$ mertakusuma99@gmail.com
}

\begin{abstract}
How to Cite :
Handayani, M., Kusuma, M. (2021). The Influence of Service Quality and Customer Relationship Management on Customer Loyalty at Bank BSI KC Bengkulu S. Parman 2. EMAK: Jurnal Ekonomi Manajemen Akuntansi Dan Keuangan, 2(4). DOI: https://doi.org/10.53697/emak.v2i4
\end{abstract}

\section{ARTICLE HISTORY}

Received [29 September 2021]

Revised [05 October 2021]

Accepted [10 October 2021)]

\section{KEYWORDS}

Service Quality, Customers' Relationship Management,

Customers' Loyalty

This is an open access article under the $C C-B Y$-SA license

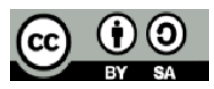

\section{ABSTRAK}

Bank Syariah Indonesia menghadirkan layanan yang lebih lengkap, jangkauan lebih luas, serta memiliki kapasitas permodalan yang lebih baik. Didukung sinergi dengan perusahaan induk (Mandiri, BNI, BRI) serta komitmen pemerintah melalui Kementerian BUMN, Bank Syariah Indonesia didorong untuk dapat bersaing di tingkat global. Penelitian ini bertujuan untuk mengetahui seberapa besar pengaruh service quality dan customer relationship managementterhadaployalitas nasabah. Dalam penelitian ini data didapatkan melalui observasi dan penyebaran kuesioner yang telah disebarkan kepada 110 responden yaitunasabah yang menabung pada Bank BSI KC Bengkulu S. Parman 2.Kemudian dilakukan analisis data menggunakan data kuantitatif. Analisis kuantitatif meliputi uji intrumen, Uji Asumsi Klasik, analisis regresi linear berganda, koefisien determinasi (R2) dan uji hipotesis. Hasil penelitian ini dapat dilihat dari uji regresi linier berganda dengan menggunakan program SPSS yaitu $Y=Y=4,388+0,158$ $(X 1)+0,357(X 2)$. Hasil koefisien determinasi (R2) nilai $R$ Square adalah 0.718 atau $71,8 \%$, dimana koefisien determinasi tersebut mempunyai arti bahwa secara bersama-sama variabelservice quality dan customer relationship management memberikan sumbangan dalam mempengaruhi loyalitas nasabah pada Bank BSI KC Bengkulu S. Parman 2, sedangkan sisanya sebesar 0.282 atau $28,2 \%$ di pengaruhi oleh variabel lain diluar penelitian yang tidak diteliti dalam penelitian ini. Pengujian hipotesis dengan menggunakan uji $\mathrm{t}$ dan uji $\mathrm{F}$ menujukkan bahwa variabel service quality (X1) dan customer relationship management (X2) berpengaruh signifikan terhadap loyalitas nasabah (Y), dimana tingkat signifikansi <0,05. Ini berarti Ho ditolak Ha diterima.

\section{ABSTRACT}

Bank Syariah Indonesia provides more complete services, wider reach, and has a better capital capacity.lt is spported by synergies with parent companies (Mandiri, BNI, BRI) and the government's commitment through the Ministry of SOEs. Bank Syariah Indonesia is encouraged to be able to compete at the global level. This study aimed to determine the effect service quality and customers' relationship management on customers' loyalty at Bank BSI KC Bengkulu S. Parman 2. This data of the study was obtained through observation and distributing questionnaire. It was distributed to 110 respondents, namely customers who saved at Bank BSI KC Bengkulu S. Parman 2. The data was analyzed by using quantitative data analysis. The 
quantitative analysis includes instrument testing, classical assumption test, multiple linear regression analysis, coefficient of determination (R2) and hypothesis testing. The results of this study can be seen from the multiple linear regression test by using the SPSS program, namely $Y=Y=4.388+$ $0.158(X 1)+0.357$ (X2). The result of the coefficient of determination (R2) the value of $R$ Square is 0.718 or $71.8 \%$, where the coefficient of determination means that together the service quality and customers' relationship management variables contribute to give effect on customers' loyalty at Bank BSI KC Bengkulu S. Parman 2, while the remaining 0.282 or $28.2 \%$ is influenced by other variables outside the study. The hypothesis testing by using $t$ test and $F$ test shows that service quality $(X 1)$ and customers' relationship management (X2) variables have a significant effect on customers' loyalty $(Y)$, where the significance level is $<0.05$. This means that $\mathrm{Ho}$ is rejected and $\mathrm{Ha}$ is accepted.

\section{PENDAHULUAN}

Persaingan dalam bisnis perbankan semakin ketat sehingga mendorong para pelaku bisnis untuk menciptakan atau menyediakan produk produk yang inovatif sehingga dapat memberikan kemudahan bagi para pelanggannya. Dukungan teknologi menjadi pilihan yangtak terelakkan untuk digunakan agar penciptaan produk yang bermutu, pelayanan yang baik dan kemudahan bagi pelanggan dapat diwujudkan, bahkan penerapan teknologi informasi menjadi salah satu faktor penentu keunggulan kompetitif dalam persaingan bisnis yang semakin tajam dan cenderung berorientasi pada customer value.

Dalam dunia jasa pelayanan, perbankan akan selalu dihadapkan pada berbagai permasalahan yang harus dihadapi, diantaranya seperti tingkat kepercayaan nasabah (trust), kepuasan nasabah (satisfaction), dan peningkatan kualitas pelayanan. Dharmayanti (2006), menjelaskan bahwa permasalahan yang mungkin muncul dalam jasa pelayanan adalah permasalahan yang berkaitan dengan ketiga hal tersebut atau variasi dari ketiganya atau permasalahan lainnya yang mungkin muncul dengan karakteristik yang bervariasi dan berbeda beda. Kemudian mereka juga menjelaskan bahwa diantara satu perusahaan dengan perusahaan lainnya permasalahan yang muncul belum tentu sama (bervariasi), misalnya jika dilihat dari kinerja para karyawan, belum tentu penilaian kinerja di restoran fast food akan sama dengan di perusahaan asuransi atau perbankan.

Manajemen pemasaran terjadi ketika setidaknya satu pihak dalam sebuah pertukaran potensial berfikir tentang cara-cara untuk mencapai respon yang diinginkan dengan pihak lain. Karenanya kita memandang manajemen pemasaran (marketing management) sebagai seni dan ilmu memilih pasar sasaran dan meraih, mempertahankan, serta menumbuhkan pelanggan dengan menciptakan, menghantarkan dan mengkomunikasikan nilai pelanggan yang unggul.

Faktor-faktor yang mempengaruhi loyalitas nasabah adalah kepuasan nasabah, kualitas produk atau pelayanan yang diberikan oleh pihak Bank, citra merek dari Bank, nilai yang dirasakan oleh nasabah, kepercayaan dari nasabah, raelasional nasabah, biaya peralihan yang rendah dan pencapaian dari Bank (reliability). Salah satu cara untuk menciptakan keunggulan bersaing adalah dengan menerapkan strategi kualitas pelayanan (service quality) yang tepat sehingga dapat memuaskan pelanggan dan untuk jangka panjang berdampak pada loyalitas pelanggan. Kualitas pelayanan (service quality) yang diberikan kepada nasabah akan memberikan kepuasan sehingga nasabah akan tetap loyal. Pelayanan yang baik menandakan bagus atau tidaknya perusahaan tersebut, pelayanan yang diberikan tersebut dapat ditunjukkan dengan kualitas pelayanan yang diberikan. Kualitas pelayanan adalah setiap tindakan atau kegiatan yang dapat ditawarkan oleh suatu pihak kepada pihak lain, yang pada dasarnya tidak berwujud dan tidak mengakibatkan kepemilikan apapun yang dilakukan oleh perusahaan guna memenuhi harapan nasabah (Philip Kotler, 2002).

Kualitas pelayanan merupakan salah satu faktor yang dapat mempengaruhi loyalitas nasabah dikarenakan nasabah yang terpuaskan nilai pribadinya dan mengalami mood yang positif terhadap pelayanan akan memiliki loyalitas yang tinggi terhadap perusahaan tersebut. Pelanggan seringkali tidak loyal disebabkan oleh adanya pelayanan yang buruk atau kualitas pelayanan yang semakin menurun dari 
yang diharapkan oleh nasabah. Kualitas pelayanan memiliki hubungan yang erat dengan loyalitas, sehingga memberikan dorongan kepada nasabah untuk menjalin ikatan yang kuat dengan perusahaan.

CRM (customer relationship management) merupakan salah satu sarana untuk menjalin hubungan yang berkelanjutan antara perusahaan dengan para stakeholder maupun shareholder-nya. Saat ini banyak perusahaan yang memanfaatkan CRM untuk menjalin hubungan erat dengan nasabah, dengan memanfaatkan CRM, perusahaan akan mengetahui apa yang diharapkan dan diperlukan nasabahnya sehingga akan tercipta ikatan emosional yang mampu menciptakan hubungan bisnis yang erat dan terbuka serta komunikasi dua arah atau timbal balik di antara mereka, dengan demikian kesetiaan nasabah dapat dipertahankan dan tidak mudah berpindah ke lain produk dan merek, terlebih produk dan merek perusahaan pesaing (Rizkiyani, 2013 dan Pambudi, 2014).

Customer Relationship Management memungkinkan bank untuk mendefinisikan dan mengidentifikasi hubungan antara nasabah dan rumah tangga perusahaan. Ini adalah langkah pertama dari proses tersebut, yang kemudian harus disebarkan di seluruh perusahaan perbankan perbankan agar dapat memperoleh keuntungan melalui rancangan produk yang lebih baik dan perhatian yang lebih besar terhadap nasabah utama (Olson dan Shi, 2008). Secara Umum CRM digunakan oleh perusahaan dalam hal ini perbankan adalah untuk aspek Customer Lifetime Value, Servise Excellent, Customer Satisfaction, dan Customer Loyality.

Tolak ukur keberhasilan suatu bank adalah salah satunya bergantung pada nasabah. Pada situasi dengan tingkat persaingan yang semakin ketat nasabah seringkali tidak mempunyai loyalitas terhadap suatu bank karena banyaknya tawaran dari bank lain yang diberikan kepada nasabah dan nasabah akan senantiasa memilih tawaran yang paling menguntungkan baginya (Pinontoan, 2013:193). Oleh karena itu, tawaran pertama yang perlu bank berikan kepada nasabah agar nasabah tersebut senantiasa tetap loyal yaitu dengan memberikan atau menawarkan produk-produk yang unggul yang tersedia di perusahaan perusahaan perbankan tersebut. Produk merupakan setiap tawaran yang dapat memuaskan kebutuhan dan keinginan (Kotler dalam Arsyad et al., 2017:51).

Bank Syariah Indonesia (BSI) merupakan Bank pada dasarnya adalah entitas yang melakukan penghimpunan dana dari masyarakat dalam bentuk pembiayaan atau dengan kata lain melaksanakan fungsi intermediasi keuangan. Dalam sistem perbankan di Indonesia terdapat dua macam sistem operasional perbankan, yaitu bank konvensional dan bank syariah. Sesuai UU No. 21 tahun 2008 tentang Perbankan Syariah, Bank Syariah adalah bank yang menjalankan kegiatan usaha berdasarkan prinsip syariah, atau prinsip hukum islam yang diatur dalam fatwa Majelis Ulama Indonesia seperti prinsip keadilan dan keseimbangan ('adl wa tawazun), kemaslahatan (maslahah), universalisme (alamiyah), serta tidak mengandung gharar, maysir, riba, zalim dan obyek yang haram. Selain itu, UU Perbankan Syariah juga mengamanahkan bank syariah untuk menjalankan fungsi sosial dengan menjalankan fungsi seperti lembaga baitul mal, yaitu menerima dana yang berasal dari zakat, infak, sedekah, hibah, atau dana sosial lainnya dan menyalurkannya kepada pengelola wakaf (nazhir) sesuai kehendak pemberi wakaf (wakif). BSI memberikan pelayanan yang memungkinkan pelanggan tetap setia dengan memberikan pelayanan berbasis syariah (islam). BSI menawarkan beberapa produk unggulan BSI diantaranya BSI Mobile, BSI Griya, BSI Oto, BSI Mitragun \& Pensiun, Debit \& Hasanah Card, BSI Gadai \& Cicil Emas, BSI Tabungan, dan BSI Priority dan BSI Mikro.

Berdasarkan hasil observasi langsung yang di laksanakan sebelumnya pada hari Senin, 5 April 2021, terdapat permasalahan mengenai loyalitas nasabah yaitu masih terlihat ragu-ragu ketika ingin menabung di Bank Syariah Indonesia (BSI) Bengkulu S. Parman 2, dikarenakan BSI merupakan Bank baru. Menurut Mizu Riyadh selaku General Affair BSI Bengkulu S. Parman 2, menyatakan bahwa jumlah nasabah yang menabung di BSI belum terlalu banyak seperti perbankan lainnya. Hal ini dikarenakan BSI yang masih tergolong Bank baru. Pegawai Bank selalu memberikan pelayanan yang maksimal untuk menarik minat nasabah untuk menabung di BSI dengan melakukan pendekatan secara langsung kepada nasabah dengan menawarkan produk-produk tabungan yang bernuansa islam.

Kemudian, dihari yang sama peneliti mencoba untuk bertanya kepada salah satu nasabah Bank BSI S. Parman 2 Kota Bengkulu kepada Bapak Selamat, mengenai kualitas pelayanan dari Bank BSI S. Parman 2 Kota Bengkulu, ia mengatakan bahwa pelayanan yang diberikan oleh pihak Bank masih dirasa kurang memuaskan, dimana beberapa pegawai masih acuh terhadap permintaan dari nasabahnya yang 
membuat nasabah kurang puas akan perlakuan yang diberikan oleh beberapa pegawai Bank, seperti pegawai Bank yang sering menunda proses pencairan apabila ada nasabah yang ingin meminjam uang dengan Bank. Namun berbeda dengan perbankan lainnya, pegawai pada Bank BSI selalu berpenampilan yang rapi dan tertutup. Selain itu, hubungan yang terjalin antara pegawai dengan nasabah (costumer releationship management), dirasa masih kurang cepat dalam menanggapi keinginan nasabahnya, dimana beberapa pegawai Bank masih terlihat acuh ketika menghadapi nasabah yang ingin komplain dengan pihak Bank yang membuat nasabah kurang puas dengan perlakuan yang diberikan oleh pihak Bank.

\section{LANDASAN TEORI}

\section{Deskripsi Konseptual}

Deskripsi konseptual merupakan suatu penentuan konsentrasi sebagai pedoman arah suatu penelian dalam upaya mengumpulkan dan mencari informasi serta sebagai pedoman dalam mengadakan pembahasan.

\section{Loyalitas Nasabah}

Loyalitas nasabah sangat penting artinya bagi perusahaan yang menjaga kelangsungan usahanya maupun kelangsungan kegiatan usahanya. nasabah yang setia adalah mereka yang sangat puas dengan produk dan pelayanan tertentu, sehingga mempunyai antusiasme untuk memperkenalkannya kepada siapapun yang mereka kenal. Selanjutnya pada tahap berikutnya nasabah yang loyal tersebut akan memperluas "kesetiaan" mereka pada produk-produk lain buatan produsen yang sama. Dan pada akhirnya mereka adalah konsumen yang setia pada produsen atau perusahaan tertentu untuk selamanya. Menurut munandar (2015:86) loyalitas adalah menciptakan hubungan yang kuat dan erat terhadap nasabah untuk jangka panjang pelanggan tidak berpindah ke perusahaan/produk lain.

\section{Service Quality}

Kata pelayanan dalam kamus besar bahasa indonesia berasal dari kata layan yang artinya membantu menyiapkan (mengurus) apa-apa yang di perlukan seseorang, sedangkan pelayanan adalah usaha untuk melayani seseorang (Departemen Pendidikan Nasional, Kamus Besar Bahasa Indonesia, Balai Pustaka jakarta, 2016). Sedangkan kualitas adalah "Totalitas dari fitur dan karakteristik suatu produk atau jasa yang memuat kemampuan untuk memberikan kepuasan teerhadap kebutuhan yang ada baik secara implisit maupun eksplisit. Kualitas produk berdampak pada kepuasan, loyalitas dan profitabilitas perusahaan (Munandar, 2016 :84).

Menurut Kotler dan Keller (2010) menyatakan bahwa pelayanan atau jasa merupakan setiap tindakan atau kegiatan yang dapat ditawarkan oleh satu pihak kepada pihak lain, pada dasarnya tidak berwujud dan tidak mengakibatkan kepemilikan apapun. Pelayanan sering sekali terkait dengan unsur jasa sehingga sering pula disebut sebagai jasa pelayanan. Jasa yang dimaksud adalah jasa yang ditawarkan perusahaan pihak perbankan dalam usaha menarik konsumen melalui pemberian pelayanan maksimal bagi konsumen pengguna jasa dari pelayanan itu sendiri.

\section{Custumer Relationship Management (CRM)}

Custumer Relationship Management (CRM) adalah suatu proses mengelola secara sungguhsungguh informasi detail mengenai penggan-pelanggan individual dan hal-hal yang berdekatan dengan pelanggan untuk memaksimalkan loyalitas pelanggan (Kotler \& Keller dikutip dalam Munandar, 2016:68). Kumar \& Reinartz $(2012 ; 38)$ dalam bukunya Customer Relationship Management : Concept, Strategy, and Tools edisi ke 2, membagi definisi Customer Relationship Management(CRM) menjadi 2 bagian. Pertama adalah definisi CRM menurut nilai pelanggan. CRM didefinisikan sebagai sebuah praktek analisa dan penggunaan database marketing serta pengaruh teknologi komunikasi untuk menentukan praktek dan metode korporasi dalam upayanya untuk meningkatkan nilai pelanggan terhadap perusahaan. Dari definisi nilai pelanggan ini, akan terdapat perbedaan dari 3 level yakni ; functional yang biasanya berhubungan dengan pemilihan teknologi, customer-facing front-end yang berhubungan dengan 
kapabilitas bisnis baru yang akan dikembangkan bagi keuntungan pelanggan, serta level strategis yang berhubungan dengan R\&D serta supply chain management (Kumar \& Reinartz, 2012; 38). Sedangkan definisi CRM jika dilihat dari sisi strategi bisnis adalah proses strategis dari pemilihan pelanggan yang dinilai perusahaan memberikan nilai tambah, dalam hal pelayanan, serta bentuk interaksi antara perusahaan dan pelanggan tersebut. Tujuan akhir dari proses ini adalah memaksimalkan keuntungan perusahaan dari pelanggan tersebut (Kumar \& Reinartz, 2012; 38). Sedangkan Adnin, Lubis, \& Widayanto (2013:3) menjelaskan jika customer relationship management adalah bisnis inti yang mengintegrasikan proses dan fungsi internal serta jaringan eksternal untuk menciptakan dan menyampaikan nilai bagi pelanggan sasaran dalam rangka mendapatkan laba. Sementara Ramu (2010:2) menyatakan bahwa customer relationship management adalah pendekatan stratejik yang memberikan perhatian dalam memberikan value kepada shareholder melalui pembangunan hubungan yang baik kepada key customer.

\section{METODE PENELITIAN}

\section{Metode Analisis}

Jenis penelitian yang digunakan dalam penelitian ini adalah metode kuantitatif. Penelitian ini merupakan penelitian yang bertujuan menjelaskan fenomena yang ada dengan menggunakan angkaangka untuk mencandarkan karakteristik individu atau kelompok (Syamsudin \& Damiyanti: 2011). Dalam penelitian ini peneliti mengumpulkan, mengolah, menyederhanakan, menyajikan dan menganalisis data secara kuantitatif (angka-angka) agar dapat memberikan gambaran yang jelas untuk memperoleh gambaran mengenai pengaruh service quality dan customer relationship management terhadap loyalitas nasabah pada Bank BSI KC. Bengkulu S. Parman 2.

Analisis regresi linear berganda ini digunakan untuk mengetahui seberapa besar pengaruh variabel independen : Service Quality $\left(\mathrm{X}_{1}\right)$ dan customer relationship management $\left(\mathrm{X}_{2}\right)$ terhadap variabel dependen yaitu loyalitas nasabah (Y) (Ghozali,2005:84). Persamaan regresi linear berganda yang dipakai adalah sebagai berikut :

$$
Y=a+b_{1} X_{1}+b_{2} X_{2}+e
$$

Keterangan :

$$
\begin{array}{ll}
\mathrm{Y} & =\text { Peningkatan penjualan } \\
\mathrm{b}_{1}-\mathrm{b}_{2} & =\text { koefisien regresi yang hendak ditafsirkan } \\
\mathrm{X}_{1} & =\text { Service Quality } \\
\mathrm{X}_{2} & =\text { Customer Relationship Management } \\
\mathrm{a} & =\text { konstanta } \\
\mathrm{e} & =\text { error }
\end{array}
$$

\section{HASIL DAN PEMBAHASAN}

\section{Hasil dan Pembahasan \\ Hasil Analisis Regeresi Linear Berganda}

Analisis regresi linear berganda yang digunakan dalam penelitian ini dengan tujuan untuk mengetahui ada tidaknya pengaruh variabel bebas terhadap variabel terikat. Perhitungan statistik dalam analisis regresi linier berganda yang digunakan dalam penelitian ini adalah dengan menggunakan bantuan program komputer SPSS V. 24 For Windows. Ringkasan hasil pengolahan data dengan menggunakan program SPSS tersebut terdapat pada tabel dibawah ini :

\section{Tabel 1. Hasil Analisis Regresi Linear Berganda}

\section{Coefficients $^{\mathrm{a}}$}

Model

$$
\begin{aligned}
& \text { Unstandardized } \\
& \text { Coefficients }
\end{aligned}
$$

\section{Standardized}

Coefficients T
Sig. 


\begin{tabular}{|c|c|c|c|c|c|c|}
\hline & & $\mathrm{B}$ & Std. Error & Beta & & \\
\hline \multirow[t]{3}{*}{1} & (Constant) & 4,388 &, 483 & & 9,091 &, 000 \\
\hline & service quality &, 158 &, 045 &, 290 & 3,485 &, 001 \\
\hline & $\begin{array}{l}\text { customer } \\
\text { relationship } \\
\text { management }\end{array}$ &, 357 &, 050 &, 600 & 7,207 &, 000 \\
\hline
\end{tabular}

a. Dependent Variable: LOYALITAS NASABAH

Sumber : Output SPSS v.24

Dari perhitungan hasil diatas didapatkan persamaan regresinya adalah sebagai berikut:

$Y=4,388+0,158\left(X_{1}\right)+0,357\left(X_{2}\right)$

Berdasarkan persamaan regresi di atas, maka dapat dijelaskan sebagai berikut :

1. Nilai Konstanta 4,388 mempunyai arti bahwa apabila variabel service quality $\left(\mathrm{X}_{1}\right)$ dan customer relationship management $\left(\mathrm{X}_{2}\right)$ terhadap loyalitas nasabah $(\mathrm{Y})$ sama dengan nol, maka variabel loyalitas nasabah akan tetap yaitu 4,388.

2. Koefisien Regresi $X_{1}$, sebesar 0,158 mempunyai makna jika nilai variabel service quality $\left(X_{1}\right)$ naik satu satuan maka nilai loyalitas nasabah $(\mathrm{Y})$ akan naik sebesar 0,158 dengan asumsi variabel customer relationship management $\left(\mathrm{X}_{2}\right)$ dianggap tetap.

3. Koefisien Regresi $X_{2}$, sebesar 0,357 mempunyai makna jika nilai variabel customer relationship management $\left(\mathrm{X}_{2}\right)$ naik satu satuan maka nilai loyalitas nasabah $(\mathrm{Y})$ akan naik sebesar 0,357 dengan asumsi variabel service quality $\left(X_{1}\right)$ dianggap tetap.

\section{Koefisien Determinasi $\left(R^{2}\right)$}

Untuk mengetahui besarnya presentase sumbangan pengaruh variabel bebas service quality $\left(\mathrm{X}_{1}\right)$ dan customer relationship management $\left(\mathrm{X}_{2}\right)$ terhadap variabel terikat loyalitas nasabah $(\mathrm{Y})$ maka dari perhitungan komputer menggunakan SPSS v.24 didapatkan uji koefisien determinasi sebagai berikut :

\section{Tabel 2. Nilai Koefisien Determinasi $\left(\mathbf{R}^{2}\right)$}

Model Summary

\begin{tabular}{ll|l|l|l} 
Model & $\mathrm{R}$ & R Square & $\begin{array}{l}\text { Adjusted } \\
\text { Square }\end{array}$ & $\begin{array}{l}\text { R } \\
\text { Std. Error of the } \\
\text { Estimate }\end{array}$ \\
\hline $1 \quad$,847 &, 718 &, 713 &, 934 \\
\hline a. Predictors: & (Constant), & CUSTOMER & RELATIONSHIP \\
\multicolumn{2}{l}{ MANAGEMENT, SERVICE QUALITY }
\end{tabular}

b. Dependent Variable: LOYALITAS NASABAH

Sumber: Output SPSS v.24

Berdasarkan tabel 4.9 di atas dapat diketahui bahwa nilai koefisien determinasi $R$ Square $\left(R^{2}\right)$ diperoleh nilai sebesar 0,718 . Nilai ini mempunyai arti bahwa variabel service quality $\left(\mathrm{X}_{1}\right)$ dan customer relationship management $\left(\mathrm{X}_{2}\right)$ terhadap variabel loyalitas nasabah memberikan sumbangan sebesar 0,718 atau 71,8\% terhadap loyalitas nasabah pada Bank BSI KC Bengkulu S. Parman 2, sedangkan sisanya sebesar 0,282 atau 28,2\% dipengaruhi oleh variabel lain yang tidak diteliti dalam penelitian ini.

\section{Pengujian Hipotesis}

Penelitian ini menguji tentang pengaruh komunikasi service quality $\left(\mathrm{X}_{1}\right)$ dan customer relationship management $\left(\mathrm{X}_{2}\right)$ terhadap loyalitas nasabah pada Bank BSI KC Bengkulu S. Parman 2. Alat analisis yang digunakan dalam pengujian hipotesis adalah Uji t dan Uji $f$ dengan menggunakan program SPSS v.24.

\section{Pengujian Hipotesis Secara Parsial (Uji t)}

Uji ini dilakukan untuk menunjukan seberapa jauh pengaruh satu variabel bebas secara individual dalam menerangkan variasi variabel tersebut. Untuk menguji pengaruh variabel bebas secara parsial terhadap variabel terikat digunakan uji $\mathrm{t}$ melalui perhitungan yang dilakukan dengan menggunakan program SPSS, maka perbandingan antara nilai $t_{\text {sign }}$ dengan tingkat kesalahan 0,05 setiap variabel sebagai berikut :

1. diterima jika nilai $t_{\text {sig }} \leq \alpha, \alpha=0,05$ 
2. ditolak jika nilai $t_{\text {sig }} \geq \alpha, \alpha=0,05$

Tabel 3. Hasil Pengujian Hipotesis dengan Uji t Coefficients $^{\mathrm{a}}$

\begin{tabular}{|c|c|c|c|c|c|c|}
\hline \multirow[b]{2}{*}{ Mod } & & \multicolumn{2}{|c|}{$\begin{array}{l}\text { Unstandardized } \\
\text { Coefficients }\end{array}$} & \multirow{2}{*}{$\begin{array}{l}\text { Standardized } \\
\text { Coefficients } \\
\text { Beta }\end{array}$} & \multirow[b]{2}{*}{$\mathrm{T}$} & \multirow[b]{2}{*}{ Sig. } \\
\hline & & $\mathrm{B}$ & Std. Error & & & \\
\hline \multirow[t]{3}{*}{1} & (Constant) & 4,388 & ,483 & & 9,091 & ,000 \\
\hline & SERVICE QUALITY &, 158 &, 045 &, 290 & 3,485 &, 001 \\
\hline & $\begin{array}{l}\text { CUSTOMER } \\
\text { RELATIONSHIP } \\
\text { MANAGEMENT }\end{array}$ & 357 & ,050 &, 600 & 7,207 &, 000 \\
\hline
\end{tabular}

a. Dependent Variable: LOYALITAS NASABAH

Sumber : Output SPSS v.24

Berdasarkan tebel diatas, berikut adalah pemaparan dari masing-masing variabel :

1. Diketahui bahwa variabel service quality berpengaruh signifikan terhadap loyalitas nasabah, dimana nilai $\mathrm{t}_{\text {sig }} \leq$ sig $\alpha=(0,001) \leq 0,05$, sehingga $\mathbf{H}_{1}$ diterima.

2. Diketahui bahwa variabel customer relationship management berpengaruh signifikan terhadap loyalitas nasabah, dimana hasil nilai $t_{\text {sig }} \leq \operatorname{sig} \alpha=(0,000) \leq 0,05$, sehingga $\mathbf{H}_{\mathbf{2}}$ diterima.

\section{Pengujian Hipotesis Secara Simultan (Uji F)}

Uji F pada dasarnya menunjukan apakah semua variabel bebas yang dimasukan kedalam model mempunyai pengaruh secara simultan terhadap variabel terikat (Kuncoro,2003). Untuk menguji pengaruh variabel bebas secara simultan terhadap variabel terikat digunakan uji $\mathrm{F}$ sebagai berikut :

Tabel 4. Hasil Pengujian Hipotesis Dengan Uji F ANOVA $^{a}$

\begin{tabular}{llll|l|l|l|l} 
Model & & $\begin{array}{l}\text { Sum } \\
\text { Squares }\end{array}$ & of & df & Mean Square & F & Sig. \\
\hline \multirow{2}{*}{1} & Regression & 237,497 & 2 & 118,748 & 136,233 & $1000^{\mathrm{b}}$ \\
\cline { 2 - 9 } & Residual & 93,267 & 107 &, 872 & & \\
\cline { 2 - 9 } & Total & 330,764 & 109 & & & \\
\hline
\end{tabular}

a. Dependent Variable: LOYALITAS NASABAH

b. Predictors: (Constant), CUSTOMER RELATIONSHIP MANAGEMENT, SERVICE QUALITY

Sumber: Output SPSS v.24

Berdasarkan tabel uji hipotesis dengan uji $F$ diatas diperoleh nilai $F_{\text {sig }} \leq \alpha=0,000 \leq 0,05$. Maka dapat disimpulkan bahwa $\mathbf{H}_{\mathbf{0}}$ diterima, artinya secara simultan variabel service quality $\left(\mathrm{X}_{1}\right)$ dan customer relationship management $\left(\mathrm{X}_{2}\right)$ berpengaruh signifikan terhadap loyalitas nasabah $(\mathrm{Y})$ pada Bank BSI KC Bengkulu S. Parman 2, sehingga $\mathbf{H}_{3}$ diterima.

\section{Pembahasan}

Pada 1 Februari 2021 yang bertepatan dengan 19 Jumadil Akhir $1442 \mathrm{H}$ menjadi penanda sejarah bergabungnya Bank Syariah Mandiri, BNI Syariah, dan BRI Syariah menjadi satu entitas yaitu Bank Syariah Indonesia (BSI). Penggabungan ini akan menyatukan kelebihan dari ketiga Bank Syariah sehingga menghadirkan layanan yang lebih lengkap, jangkauan lebih luas, serta memiliki kapasitas permodalan yang lebih baik. Didukung sinergi dengan perusahaan induk (Mandiri, BNI, BRI) serta komitmen pemerintah melalui Kementerian BUMN, Bank Syariah Indonesia didorong untuk dapat bersaing di tingkat global.

494 | Mita Handayani, Merta Kusuma; The Influence of Service Quality and... 
Penggabungan ketiga Bank Syariah tersebut merupakan ikhtiar untuk melahirkan Bank Syariah kebanggaan umat, yang diharapkan menjadi energi baru pembangunan ekonomi nasional serta berkontribusi terhadap kesejahteraan masyarakat luas. Keberadaan Bank Syariah Indonesia juga menjadi cerminan wajah perbankan Syariah di Indonesia yang modern, universal, dan memberikan kebaikan bagi segenap alam (Rahmatan Lil 'Aalamiin).

Hasil dari penyebaran kuesioner kepada 110 orang yang dijadikan sebagai responden yaitu nasabah yang menabung di Bank BSI KC Bengkulu S. Parman 2 dapat diperoleh bahwa variabel sevice quality dan customer relationship management berpengaruh signifikan terhadap loyalitas nasabah. Adapun hasil uji hipotesis secara parsial (Uji t) dan uji hipotesis secara simultan (Uji f) dijabarkan sebagai berikut:

\section{Pengaruh Service Quality Terhadap Loyalitas Nasabah}

Berdasarkan kriteria penilaian tanggapan responden mengenai variabel service quality adalah pada kategori baik. Berarti service quality yang diberikan oleh Bank BSI KC Bengkulu S. Parman 2 sudah baik menurut nasabahnya. Diamana hasil penelitian menunjukkan bahwa service quality berpengaruh signifikan terhadap loyalitas nasabah, dimana nilai $t_{\text {sig }}(0,001) \leq 0,05$, yang artinya $\mathbf{H}_{\mathbf{1}}$ diterima. Berdasarkan observasi awal yang telah peneliti lakukan, diketahui bahwa pelayanan yang diberikan oleh pihak Bank masih dirasa kurang memuaskan, dimana beberapa pegawai masih acuh terhadap permintaan dari nasabahnya yang membuat nasabah kurang puas akan perlakuan yang diberikan oleh beberapa pegawai Bank, seperti pegawai Bank yang sering menunda proses pencairan apabila ada nasabah yang ingin meminjam uang dengan Bank. Namun, setelah melakukan penelitian ternyata hal tersebut berbeda dengan hasil observasi awal yang telah peneliti lakukan, dimana pada saat ini pegawai Bank akan tetap melayani nasabahnya yang telah datang duluan untuk melakukan transaksi dengan Bank, karena dengan memberikan pelayanan semaksimal mungkin kepada nasabah dapat mempengaruhi loyalitas nasabah terhadap perusahaan. Apabila kualitas pelayanan yang diberikan perusahaan sesuai dengan harapan dan kinerja maka nasabah akan senang karena harapan dan kinerja dari pelayanan tersebut sudah baik dan loyalitas nasabah secara langsung akan timbul pada perusahaan tersebut.

Kualitas pelayanan memiliki pengaruh yang erat dalam meningkatkan kepuasan nasabah untuk menunjang loyalitas nasabah. Menurut Kotler (2003), kualitas pelayanan dapat memberikan suatu dorongan kepada nasabah untuk menjalin ikatan hubungan yang kuat dengan Bank. Dalam jangka panjang ikatan seperti ini memungkinkan perusahaan untuk memahami dengan seksama harapan nasabah serta kebutuhan mereka. Dengan demikian, perusahaan dapat meningkatkan kepuasan pelanggan melalui pemberian pelayanan yang menyenangkan tentu akan tercipta loyalitas yang tinggi pada konsumen terhadap perusahaan, (Tjiptono, 2006). Dari penjelasan di atas, diketahui bahwa kualitas pelayanan memiliki penggaruh yang baik dalam meningkatkan kepercayaan nasabah terhadap perusahaan. Apabila nasabah yang datang mendapatkan pelayanan yang baik dari perusahaan maka, mereka akan terpuaskan dan akan loyal terhadap perusahaan tersebut. Loyalitas pelanggan tercipta karena adanya hubungan yang baik antara nasabah dengan perusahaan dan hubungan yang baik itu tercipta karena adanya kepuasan dari nasabah. Griffin (2005) menjelaskan bahwa apabila penilaian nasabah merasa baik terhadap kualitas pelayanan, maka pelanggan akan melakukan pemakaian ulang (repeat customer), bahkan lebih jauh lagi mereka akan melakukan promosi word of mouth kepada rekan, saudara dan kenalannya, dan memiliki kekebalan atas tawaran pesaing.

Hasil penelitian ini sejalan dengan hasil penelitian yang dilakukan oleh Dety Meilina (2017), Felicia Laurent (2016), dan Agnes Laurencia Setiawan (2015) yang menyatakan bahwa service quality berpengaruh signifikan terhadap loyalitas nasabah. Hal ini menjelaskan bahwa pelayanan yang baik sangat diperlukan dalam menciptakan loyalitas nasabah, karena dapat mempengaruhi keberhasilan suatu usaha.

\section{Pengaruh Customer Relationship Management Terhadap Loyalitas Nasabah}

Berdasarkan kriteria penilaian tanggapan responden menunjukan bahwa rata-rata penilaian responden mengenai variabel customer relationship management adalah pada kategori baik. Berarti hubungan yang terjalin antara pihak Bank dengan nasabahnya sudah berjalan dengan baik, dimana hasil 
penelitian menunjukkan bahwa customer relationship management berpengaruh signifikan terhadap loyalitas nasabah, dengan nilai $t_{\text {sig }}(0,000) \leq 0,05$, sehingga $\mathbf{H}_{\mathbf{2}}$ Diterima.

Berdasarkan observasi awal yang telah peneliti lakukan menunjukan bahwa hubungan yang terjalin antara pegawai dengan nasabah (costumer releationship management), dirasa masih kurang cepat dalam menanggapi keinginan nasabahnya, dimana beberapa pegawai Bank masih terlihat acuh ketika menghadapi nasabah yang ingin komplain dengan pihak Bank yang membuat nasabah kurang puas dengan perlakuan yang diberikan oleh pihak Bank. Namun, setelah melakukan penelitian ternyata hal tersebut berbeda dengan hasil penelitian yang telah peneliti lakukan, dimana nasabah sudah percaya bahwa bertransaksi pada Bank BSI selalu memberikan rasa aman dan pegawai Bank akan membantu nasabahnya apabila mereka memiliki kesulitan dalam melakukan transaksi. Jika hubungan yang terjalin antara pegawai Bank dengan nasabahnya berjalan dengan baik, maka loyalitas nasabah terhadap perusahaan akan meningkat.

Menurut pendapat Kotler dan Keller (2007), customer relationship manajemen memiliki pengaruh terhadap loyalitas nasabah dimana kualitas hubungan yang berfokus pada pelanggan akan tercipta kepuasan dan pelanggan yang puas biasanya tetap setia untuk menggunakan kembali meskipun dengan jangka waktu yang lama yaitu sebagai loyalitas nasabah. Hubungan yang baik dengan nasabah adalah sebuah kunci keberhasilan suatu perusahaan dalam mempertahankan perusahaanya dalam industri. Ketika perusahaan telah berkomitmen untuk mempertahankan nasabah melalui pelayanan pelanggan yang istimewa agar terciptanya hubungan pelanggan sejati, dimana komitmen tersebut membutuhkan biaya terkait dengan daya tarik karyawan, ketahanan dan training, seperti juga biaya untuk menyediakan elemen-elemen dari total penawaran yang dinilai oleh pelanggan.

Agustiyadi (2008) menyatakan bahwa salah satu cara untuk meningkatkan loyalitas nasabah adalah dengan mengelola hubungan perusahaan dengan nasabah atau Customer Relationship Management (CRM) sehingga kedua belah pihak memperoleh nilai yang maksimum dari hubungan tersebut. Konsep CRM menekankan pada pendekatan untuk membangun portofolio melalui jalinan bisnis yang terbentuk dengan pelanggan melalui interaksi, memberdayakan hubungan yang terbentuk, pembentukan jaringan, dan meningkatkan komunikasi dalam rangka menumbuhkan loyalitas pelanggan. Hubungan yang baik dengan nasabah adalah sebuah kunci keberhasilan suatu perusahaan dalam mempertahankan perusahaanya dalam industri. Ketika perusahaan telah berkomitmen untuk mempertahankan nasabah melalui pelayanan pelanggan yang istimewa agar terciptanya hubungan pelanggan sejati, dimana komitmen tersebut membutuhkan biaya terkait dengan daya tarik karyawan, ketahanan dan training, seperti juga biaya untuk menyediakan elemen-elemen dari total penawaran yang dinilai oleh pelanggan. Menurut Kotler dan Amstrong (2008) menjelaskan bahwa manajemen hubungan nasabah (customer relationship management) adalah proses mengelola informasi rinci tentang nasabah perorangan dan semua 'titik kontak' nasabah secara seksama untuk memaksimalkan loyalitas nasabah.

Hasil penelitian ini sejalan dengan hasil penelitian yang dilakukan oleh Lisnawati (2015), Agnes Laurencia Setiawan (2015) dan Kartika Irmasari dan Kezi Kurniawati Nursalin (2013) yang menyatakan bahwa customer relationship management berpengaruh signifikan terhadap loyalitas nasabah. Hal ini menjelaskan bahwa customer relationship management atau hubungan yang terjalin antara pegawai Bank dengan nasabah memiliki peranan penting dalam suatu usaha, karena dapat mempengaruhi keberhasilan perusahaan untuk meningkatkan kepercayaan nasabah terhadap perusahaan. Berdasarkan teori pendukung dan penelitian terdahulu dapat disimpulkan bahwa customer relationship management dapat mempengaruhi loyalitas nasabah.

\section{Pengaruh Service Quality Dan Customer Relationship Management Terhadap Loyalitas Nasabah}

Berdasarkan hasil uji $\mathrm{F}$ menunjukkan bahwa ada pengaruh signifikan antara variabel service quality $\left(X_{1}\right)$ dan customer relationship management $\left(X_{2}\right)$ terhadap loyalitas nasabah yang dibuktikan dari hasil nilai $F_{\text {sig }}(0,000) \leq 0,05$, sehingga $\mathbf{H}_{3}$ Diterima. Hal ini berarti variabel independen dan dependen memiliki hubungan yang kuat dan pengaruhnya signifikan. Service quality dan customer relationship management memiliki pengaruh signifikan terhadap loyalitas nasabah pada Bank BSI KC Bengkulu S. Parman 2, dimana dengan memberikan pelayanan semaksimal mungkin dan menjalin hubungan yang 
harmoni dengan nasabah akan menciptakan rasa aman bagi nasabah yang membuat nasabah loyal terhadap perusahaan.

Mendapatkan kepercayaan dari nasabah sangat diperlukan dalam menjalankan suatu usaha. Jika nasabah puas dengan pelayanan yang diberikan akan menciptakan nasabah yang setia untuk selanjutnya. Perasaan senang atau kecewa seseorang muncul ketika telah membandingkan antara kinerja pelayanan dengan persepsi yang diharapakan (Kotler dan Amstrong, 2012). Hubungan antara pegawai Bank dengan nasabah harusla benar-benar berjalan dengan lancar. Perusahaan selalu mendekatkan diri dengan masyarakat agar dapat dikenal oleh masyarakat umum. Selain itu, perusahaan harus secara luas mengakui bahwa pelanggan merupakan aset yang sangat penting dan melihat customer relationship management sebagai kerjasama yang meguntungkan dan sebagai peluang yang dibutuhkan manajemen (Plakoyiannaki, 2005).

\section{KESIMPULAN DAN SARAN}

\section{Kesimpulan}

1. Servicee quality berpengaruh signifikan terhadap loyalitas nasabah pada Bank BSI KC Bengkulu S.Parman 2.

2. Customer relationship management berpengaruh signifikan terhadap loyalitas nasabah pada Bank BSI KC Bengkulu S.Parman 2.

3. Service quality dan customer relationship management berpengaruh signifikan terhadap loyalitas nasabah pada Bank BSI KC Bengkulu S.Parman 2.

\section{Saran}

1. Pada variabel service quality memiliki tanggapan responden terendah sebesar 3.70. Disarankan untuk lebih baiknya lagi kepada pihak Bank agar dapat melayani nasabahnya tanpa memandang siapa nasabah tersebut. Dengan demikian nasabah yang lain tidak akan kecewa dengan pelayanan yang diberikan oleh pihak Bank.

2. Hasil penelitian terlihat bahwa pada variabel customer relationship management memiliki tanggapan responden yang terendah yaitu 3.76. Disarankan kepada pihak Bank agar selalu meningkatkan kepercayaan nasabahnya dengan cara terus melakukan pendekatan dengan masyarakat agar masyarakat tetap percaya dengan perusahaan dan dapat menjaga kesetian nasabah terhadap perusahaan.

3. Hasil penelitian terlihat bahwa pada variabel loyalitas nasabah memiliki tanggapan responden yang terendah yaitu 4,04. Disarankan kepada pihak Bank agar dapat meyakinkan nasabahnya akan kelebihan dan keunggulan produk yang mereka tawarkan agar nasabah dapat membandingkan antara keinginan dan harapan yang telah mereka tawarkan.

4. Disarankan bagi peneliti selanjutnya khususnya penelitian yang sama perlu dipertimbangkan untuk faktor-faktor lain diluar variabel service quality dan customer relationship management terhadap loyalitas nasabah serta dapat meningkatkan kepercayaan nasabah terhadap perusahaan sehingga akan menghasilkan penelitian yang lebih baik.

\section{DAFTAR PUSTAKA}

Akbar M.M and Parvez, (2009). Impact of Service Quality, Trust, and Customer Satisfaction Loyalty, ABAC Journal, Vol. 29, No.1.Januari, 24-38.

Amalia, Dina. (2014) "Hubungan Customer Relationship Management Dengan Loyalitas Nasabah", Jakarta. Ariyani Ferlina, (2008). "Membangun Loyalitas Nasabah Melalui Peningkatan Kualitas Pelayanan dan Keunggulan Produk". Universitas Dipenogoro Semarang002E 
Astuti, Wiji dan Muchtas Rizka. (2013). "Customer Loyalty the Effects of Service Quality and The Mediating Role of Customer Relationship Marketing Telkom Speedy in Jember Area". Reiew of integrative business \& Economics Research In Science. Vol, S(1), 243-249.

Brown, Kaneth G, (2011). Human Reseurce Management 2nd Edition : Linking Strategy To Practice. United States Of America: Jhon Wiley And Sons, Inc.

Cooper, Donald R., dan Emory, William C, (2006). Metode Penelitian Bisnis. Erlangga, Jakarta.

Ghazian, Asieha, dkk. (2016). "The Effect of Customer Relationship Management and its Significant Relationship by Customers Reactions in LG Company", Procedia Economics and Finance 36.

Ghozali, Imam. (2005). Aplikasi Analisis Multivariate dengan SPSS. Semarang: Badan Penerbit UNDIP. (2007), Aplikasi Analisis Multivariate Dengan Program SPSS, Semarang: Universitas Diponogoro.

(2012). Aplikasi Analisis Multivariate dengan Program IBM SPSS. Yogyakarta: Universitas Diponegoro.

Griffin, Jill, (2005). Customer Loyalty : Menumbuhkan dan Mempertahankan Kesetian Pelanggan. Jakarta : Erlangga.

Hair, Jr et.al. (2010). Multivariate Data Analysis (7th). United States : Pearson.

Hasan, Ali. (2014). Marketing dan Kasus-Kasus Pilihan. Yogyakarta : CAPS.

Isnadi Didik, (2005). "Analisis Pengaruh Customer Relationship Marketing Terhadap Nilai Nasabah Dan Keunggulan Produk Dalam Meningkatkan Kepuasan dan Loyalitas Nasabah". Semarang: Universitas Diponegoro.

Kalalo Inn E, (2013). "Customer Relationship Management dan Kualitas Pelayanan Terhadap Loyalitas Konsumen PT. Matahari Dept.Store", Manado.

Kasmir. "Pemasaran Bank", (2005). Jakarta Kencana. edisi perama cetakan pertama.

Kotler, P. (2005) Manajemen Pemasaran. Edisi Kesebelas. Jilid 2, Jakarta: PT. Indeks Kelompok Gramedia.

Kotler, Philip dan Kevin Lane Kotler, (2007). Manajemen Pemasara. Edisi 1 Jilid 2. Jakarta : PT Macanan Jaya Cemerlang.

(2012). Marketing Management. Global Edition. New Jersey :Pearson Prentice Hall.

Kotler And Amstrong, (2008). Prinsip-prinsip Pemasaran Edisi 12 Jilid 1. Jakarta: Erlangga

Kotler, Philip and Gary Armstrong. (2014), Principles of Marketing. 15th Edition, New Jersey: Pearson Pretice Hall.

Kumar, V. \& Werner Reinartz. (2012). Customer Relationship Management : Concept, Strategy, and Tools. Springer.

Lisnawati, (2015). "Pengaruh Customer Relationship Management terhadap Loyalitas Nasabah (Survei pada Nasabah Asuransi Jiwa Prudential Cabang Kota Bandung)", April 2015.

Lupioyadi, R. (2001). Manajemen Pemasaran Jasa : Teori dan Praktek (Service Marketing Management: Theory and Practice). Jakarta : Salemba empat.

Nurlaila, Intan. (2014). Pengaruh Kualitas Pelayanan, Inovasi, dan Citra Perusahaan Terhadap Loyalitas Pelanggan Melalui Kepuasan Pelanggan Pada Erha Clinic di Surabaya. Diakses dari: http://repository.wima.ac.id/

Qomariah, Nurul. (2012). Pengaruh Kualitas Layanan dan Citra Institusi Terhadap Kepuasan dan Loyalitas Pelanggan. Jurnal Aplikasi Manajemen Volume 10 Nomor 1.

Rahmawati, novia. (2016). Pengaruh Relationship Marketing terhadap Loyalitas Nasabah pada PT. Bank Negara Indonesia Cabang Malang. Skripsi, Universitas Brawijaya Malang.

Shofwa, Yoiz. (2015). "Pengaruh Kualitas Produk Dan Religiusitas Terhadap Keputusan Nasabah Produk Simpanan Pada BSM Cabang Purwokerto", Penelitian Individual Kemenag

Silmi, Sulhida. (2012). "Persepsi Nasabah Tentang Relationship Marketing dan Pengaruhnya Terhadap Loyalitas (Studi Pada Nasabah Tabungan Utama PT. Bank Mega Syariah Cabang Malang)". Jurnal Manajemen Pemasaran 8(1):1 14.

Sivesan. (2012). Impact of Relationship Marketing on Costumer Loyalty on BankingSectors. Jurnal of South Academic Research. Volume 2, Issue 3, pp. 179-191.

Sondakh, Conny. (2014). Kualitas Layanan, Citra Merek dan Pengaruhnya Terhadap Kepuasan Nasabah dan Loyalitas Nasabah Tabungan (Studi Pada Nasabah Jurnal Riset Bisnis dan Manajemen Tirtayasa 214 Taplus BNI Cabang Manado). Jurnal Riset Bisnis dan Manajemen Vol.3 No.1

498 | Mita Handayani, Merta Kusuma; The Influence of Service Quality and... 
Sugiyono. (2012). Metode Penelitian Kuantitatif Kualitatif dan R\&B. Bandung: Alfabeta.

(2013). Metode Penelitian Pendidikan Pendekatan Kuantitatif, Kualitatif, dan R\&D. Bandung: Alfabeta.

Wijayanto, kusuma, (2015). "Pengaruh Kualitas Pelayanan Terhadap Kepuasan Dan Loyalitas Nasabah Bank", Jurnal Ekonomi Managemen Sumber Daya, Vol. 17, No.1.

Zulfah lailatul, (2008). "Pengaruh Kualitas Produk Dan Kualitas Pelayanan Terhadap Kepuasan Nasabah Tabungan Haji Pada BNI Syariah Cabang Jakarta Timur", Universitas Syarif Hidayatullah Jakarta. 